\title{
Hematological parameters and selected intestinal microbiota populations in the Indonesian indigenous crossbred chickens fed basal diet supplemented with multi-strain probiotic preparation in combination with vitamins and minerals
}

\author{
Sugiharto Sugiharto, Turrini Yudiarti, Isroli Isroli, Endang Widiastuti and Hanny I. Wahyuni \\ Department of Animal Science, Faculty of Animal and Agricultural Sciences, Diponegoro University, Semarang, \\ Central Java, Indonesia. \\ Corresponding author: Sugiharto Sugiharto, e-mail: sgh undip@yahoo.co.id \\ Co-authors: TY: tyudiarti@yahoo.co.id, II: isroliundip02@yahoo.com, \\ EW: endwidia@yahoo.co.id, HIW: hihannyiw123@gmail.com \\ Received: 15-03-2018, Accepted: 22-05-2018, Published online: 29-06-2018
}

doi: 10.14202/vetworld.2018.874-882 How to cite this article: Sugiharto S, Yudiarti T, Isroli I, Widiastuti E, Wahyuni HI (2018) Hematological parameters and selected intestinal microbiota populations in the Indonesian indigenous crossbred chickens fed basal diet supplemented with multi-strain probiotic preparation in combination with vitamins and minerals, Veterinary World, 11(6): 874-882.

\begin{abstract}
Aim: The aim of this study was to investigate the effect of dietary supplementation with multi-strain probiotic preparation in combination with vitamins and minerals on the hematological parameters and selected intestinal microbiota populations in the Indonesian indigenous crossbred chickens.

Materials and Methods: A total of 240 one-day-old Indonesian indigenous crossbred chicks were raised for 10 weeks. The chicks were distributed to one of four groups, i.e., chicks receiving basal diet without any additive (CONT), chicks receiving basal diet with $0.04 \%$ of zinc bacitracin (AGP), chicks receiving basal diet with $0.01 \%$ of commercial probiotic Bacillus subtilis preparation (PROB1), and chicks receiving basal diet with $0.5 \%$ of multi-strain probiotic preparation in combination with vitamins and minerals (PROB2). Blood was collected on the week 8 , while the internal organs and eviscerated carcasses were collected on the week 10.

Results: PROB2 tended ( $\mathrm{p}=0.09$ ) to have a lower body weight $(\mathrm{BW})$ compared to CONT chicks. Feed conversion ratio was higher $(\mathrm{p}<0.05)$ in PROB1 and PROB2 compared to CONT birds. The number of thrombocytes tended $(\mathrm{p}=0.09)$ to be higher in CONT than in other groups. Antibody titer against Newcastle disease virus vaccine was higher $(\mathrm{p}<0.05)$ in PROB1 and PROB2 than in CONT group. Serum triglyceride concentration was lower $(p<0.05)$ in PROB2 than in other birds. AGP chicks had lower $(\mathrm{p}<0.05)$ serum total protein and globulin concentrations than CONT and PROB1 chicks. Serum albumin level was lower $(\mathrm{p}<0.05)$ in PROB2 than in CONT and PROB1 birds. Albumin to globulin ratio tended $(\mathrm{p}=0.06)$ to be higher in AGP than in other birds. Lactose-negative Enterobacteriaceae tended $(\mathrm{p}=0.07)$ to be lower in PROB1 and PROB2 than in CONT group. PROB1 and PROB2 tended $(\mathrm{p}=0.06)$ to have greater lactic acid bacteria (LAB) population than in CONT and AGP birds.
\end{abstract}

Conclusion: Multi-strain probiotic preparation in combination with vitamins and minerals was able to improve immune response and control the potentially pathogenic bacteria. However, the additive could not improve the growth performance of the Indonesian indigenous crossbred chickens.

Keywords: growth performance, Indonesian indigenous crossbred chickens, intestinal bacteria, minerals, multi-strain probiotic, vitamins.

\section{Introduction}

The Indonesian indigenous crossbred chicken is the crossbred offspring of male Indonesian indigenous chicken and female modern chicken (i.e., Isa Brown hen) [1]. The chickens have the exterior appearance and meat characteristics similar to indigenous chickens, but they can reach marketing weight at an earlier age than indigenous chickens $[2,3]$. With intensive rearing

Copyright: Sugiharto, et al. Open Access. This article is distributed under the terms of the Creative Commons Attribution 4.0 International License (http://creativecommons.org/licenses/ by/4.0/), which permits unrestricted use, distribution, and reproduction in any medium, provided you give appropriate credit to the original author(s) and the source, provide a link to the Creative Commons license, and indicate if changes were made. The Creative Commons Public Domain Dedication waiver (http:// creativecommons.org/publicdomain/zero/1.0/) applies to the data made available in this article, unless otherwise stated. system, the Indonesian indigenous crossbred chickens can reach $850 \mathrm{~g}$ at 60-70 days, while indigenous chickens can only reach $500 \mathrm{~g}$ at the same age $[1,4]$. In-feed antibiotics have previously been used to optimize the growth potential and maintain the health status of the Indonesian indigenous and indigenous crossbred chickens [5]. The use of such antibiotics in poultry feed may, however, lead to a controversy related to antibiotic resistance in bacteria both in animals and humans as consumers [6]. With the food safety reason, the application of in-feed antibiotics as growth promoters and antimicrobial agents has been banned in many countries including Indonesia.

At present, there is a growing interest in using antibiotic substitutes in poultry nutrition. Among the substitutes, probiotics have gained more attention 
from poultry nutritionists. When given in adequate numbers, probiotics can exert health benefits on the host by maintaining a microbial balance in the intestine and improving the intestinal functions [6]. Various types of microorganisms are currently used as probiotics, and that lactic acid bacteria (LAB) are the most common type of bacteria used as probiotics for poultry. In addition to the $\mathrm{LAB}$, probiotic containing Bacillus spp. has also attracted considerable interest from the poultry nutritionists. In general, Bacillus spp. is able to form endospores, which make Bacillusbased probiotics not only could survive in the extreme condition in the gastrointestinal tract but also have better viability and stability especially during feed processing and storage [7]. The latter properties make Bacillus probiotics seems to be more effective and practical, as compared to LAB-based probiotics, in poultry production.

Under a certain condition such as heat stress, extra supplementations of vitamins, minerals, and probiotics and other additives have commonly been conducted to maintain the health and promote growth rate in broilers fed commercial rations [8]. With regard to probiotics, such additive has often been used in combination with vitamins and minerals to further exert positive impacts on the host. Indeed, daily supplementation of probiotic bacteria plus vitamins and minerals improved immunity and protected the human body from infections, better than placebo [9]. In poultry, we have recently shown that supplementation with probiotic Bacillus plus vitamins and minerals (later called multi-strain probiotic preparation in combination with vitamins and minerals) improved physiological conditions and intestinal development of broiler chicks during the brooding period [10]. The treatment also improved digestive functions, physiological status, and an intestinal population of the LAB in broiler chickens $[11,12]$. The use of such latter additive has, however, never been reported in the Indonesian indigenous crossbred chickens.

The aim of this study was to investigate the effect of dietary supplementation with multi-strain probiotic preparation in combination with vitamins and minerals on the hematological parameters and selected intestinal microbiota populations in the Indonesian indigenous crossbred chickens.

\section{Materials and Methods}

Ethical approval

The trial was carried out following the standard procedures of rearing and treating of farm animals stated in law of the Republic of Indonesia number 18, 2009, regarding animal husbandry and health.

\section{Experimental design and management}

Two hundred and forty one-day-old Indonesian indigenous crossbred chicks (body weight $[\mathrm{BW}]=37.8 \pm 0.17 \mathrm{~g}$ and means \pm standard deviation) were raised for 10 weeks. In the present study, the chicks were not sexed. Different from broiler chicks, sexing is not commonly done for 1-day-old Indonesian crossbred chicks [13]. At day 0, the chicks were weighed and randomly distributed to one of four experimental groups of 60 chicks each (6 replicates of 10 chicks). The birds were raised in an open-sided house with a wire floor pens throughout the experiment. Light was provided $24 \mathrm{~h}$ per day. Plastic curtains, light bulbs (as a heater), and blower fans were installed to control temperature and humidity of the poultry house. The experimental groups included chicks receiving basal diet without any additive (CONT), chicks receiving basal diet with $0.04 \%$ of zinc bacitracin (AGP), chicks receiving basal diet with $0.01 \%$ of commercial probiotic Bacillus subtilis preparation (PROB1), and chicks receiving basal diet with $0.5 \%$ of multi-strain probiotic preparation in combination with vitamins and minerals (PROB2). The additives were added at the expense of the basal diets. The diets (in mash form) and water were provided ad libitum throughout the study period. The diets were free from coccidiostat, enzymes, and other feed additives/supplements. As there is no standard of nutrient requirement for the Indonesian indigenous crossbred chickens, the basal diet was formulated (Table-1) $[12,14]$ according to the nutrient requirement for broiler chickens (the Indonesian National

Table-1: Ingredients and chemical composition (as-dry basis) of basal diet provided to the Indonesian indigenous crossbred chickens ${ }^{1}$.

\begin{tabular}{lc}
\hline Items & $\begin{array}{c}\text { Composition } \\
\text { (\%, unless otherwise noted) }\end{array}$ \\
\hline Yellow corn & 45.5 \\
Soybean meal & 17.0 \\
Wheat flour & 10.0 \\
Bread flour & 5.00 \\
Rice bran & 4.45 \\
Crude palm oil & 3.50 \\
Corn gluten meal & 3.60 \\
Distiller dried grains & 3.00 \\
Meat bone meal & 2.80 \\
Hydrolyzed chicken & 2.00 \\
feather meal & \\
Bone meal & 1.50 \\
Lysine & 0.55 \\
Methionine & 0.37 \\
L-threonine & 0.08 \\
Salt & 0.15 \\
Premix 2 & 0.50 \\
Analyzed composition & \\
Metabolizable & 3286 \\
energy (kcal/kg) & \\
Crude protein & 21.7 \\
Crude fat & 5.90 \\
Crude fiber & 6.79 \\
Ash & 10.9
\end{tabular}

${ }^{1}$ The basal diet was similar as used in Sugiharto et al. [12]. ${ }^{2}$ Mineral-vitamin premix contained (per $\mathrm{kg}$ of diet) of Ca $2.250 \mathrm{~g}, \mathrm{p} 0.625 \mathrm{~g}$, Fe $3.570 \mathrm{mg}$, Cu $0.640 \mathrm{mg}$, Mn 5.285 mg, Zn 0.003 mg, Co 0.001 mg, Se 0.013 mg, I 0.016 mg, Vitamin A 375 IU, Vitamin D 150 IU, Vitamin E $0.080 \mathrm{mg}$. ${ }^{3}$ Value was calculated according to formula[14] as follow: 40.81 ( 0.87 [crude protein +2.25 crude fat + nitrogen free extract $]+2.5)$. $\mathrm{CP}=$ Crude protein 
Standards for Broiler Feed) [15]. The diet contained $21.7 \%$ crude protein and $3.286 \mathrm{kcal} / \mathrm{kg}$ metabolizable energy (determined according to Bolton [14]). The diet was prepared as a single diet and provided throughout the experiment. The multi-strain probiotic preparation contained $12.10 \log \mathrm{cfu} / \mathrm{g}$ multi-strains Bacillus (i.e., Bacillus cereus strain SIIA_Pb_E3, Bacillus licheniformis strain FJAT-29133, Bacillus megaterium strain F4-2-27, and Bacillus spp. 11CM31Y12), $0.100 \mathrm{mg}$ Vitamin A, $0.018 \mathrm{mg}$ Vitamin $\mathrm{D}_{3}, 0.100 \mathrm{mg}$ Vitamin E, $1200 \mathrm{mg} \mathrm{Ca}, 750 \mathrm{mg} \mathrm{P,} 0.08 \mathrm{mg} \mathrm{Mg}$, $0.006 \mathrm{mg} \mathrm{Co}, 0.045 \mathrm{mg} \mathrm{Cu}, 0.015 \mathrm{mg} \mathrm{Se}, 0.180 \mathrm{mg}$ $\mathrm{S}, 0.010 \mathrm{mg} \mathrm{Zn}, 0.060 \mathrm{mg} \mathrm{KCl}, 0.030 \mathrm{mg}$ I, $0.060 \mathrm{mg}$ $\mathrm{Fe}$, and $0.100 \mathrm{mg} \mathrm{Mn} \mathrm{[10-12].}$

At day 0 , commercial Newcastle disease virus (NDV) and avian influenza virus (AIV) vaccines were administrated intramuscularly. Birds were subsequently vaccinated with NDV vaccine through drinking water at week 2 and 5 . At the end of the trial, live BW and accumulative feed intake (FI) of chicks were recorded. For complete blood counts and serum biochemical analyses, blood was obtained from the bird's wing veins ( 6 birds per treatment) and placed in ethylenediaminetetraacetic acid-containing vacutainers and vacutainers without anticoagulant, respectively, at week 8 . Blood in the latter vacutainers was permitted to clot at room temperature and centrifuged at $448 \mathrm{~g}$ for 15 min to produce serum. The serum was frozen until analyses [16]. Only male birds from each replicate were used for blood collection. At the end of the study (week 10), the same birds that were blood sampled (6 birds per treatment) were slaughtered, de-feathered, and eviscerated. Immediately, the immune and visceral organs were obtained and weighed [16]. For the bacteriological analysis, ileum (from Meckel's diverticulum to a point $4 \mathrm{~cm}$ proximal to the ileocecal junction) was gently squeezed, and digesta was expelled into the sterile sample bottles. Carcass traits of chicks were determined according to Sugiharto et al. [11].

A full blood count was measured using a hematology analyzer (Prima Fully-auto Hematology Analyzer, PT. Prima Alkesindo Nusantara, Jakarta, Indonesia) according to the manufacturer's instructions. The serum NDV and AIV antibody titers were determined based on hemagglutination inhibition (HI) test [17]. The titers were showed as geometric mean titers $\left(\log _{2}\right)$. The enzymatic colorimetric/color method was used to measure the levels of total triglyceride, total cholesterol, high-density lipoprotein, and low-density lipoprotein cholesterol in serum. Total protein and albumin in serum were determined according to the spectrophotometric/photometric tests. The difference between total protein and albumin in serum was assigned as the values of globulin. The biochemical analyses in serum were conducted using kits (DiaSys Diagnostic System GmbH, Holzheim, Germany) according to the manufacturer's instructions. The selected bacterial populations in the ileal digesta of chicks were determined based on Sugiharto et al. [18]. Coliform bacteria and lactose-negative Enterobacteriaceae were counted on MacConkey agar (Merck KGaA, Darmstadt, Germany) after aerobic incubation at $38^{\circ} \mathrm{C}$ for $24 \mathrm{~h}$ as red and colorless colonies, respectively. The numbers of coliform and lactose-negative Enterobacteriaceae were assigned as enterobacteria. LAB were counted on de Man, Rogosa and Sharpe (MRS; Merck KGaA, Darmstadt, Germany) agar following anaerobic incubation at $38^{\circ} \mathrm{C}$ for $48 \mathrm{~h}$.

\section{Statistical analysis}

The data were analyzed based on a completely randomized design by ANOVA using the General Linear Models Procedure in SAS (SAS Inst. Inc., Cary, NC, USA). The pen was regarded as the experimental unit. The significant differences $(p<0.05)$ among experimental groups were further analyzed using Duncan's Multiple Range Test.

\section{Results}

\section{Production performances of chicks}

The data on final BW, accumulative FI and feed conversion ratio (FCR) are presented in Table-2. The significant difference was not observed in the final BW of crossbred chickens, but there was a tendency $(p=0.09)$ that chicks in the PROB2 group had lower final BW as compared to CONT group. FCR was higher $(\mathrm{p}<0.05)$ in PROB1 and PROB2 as compared to CONT, but the difference was not observed between PROB1 and AGP and between PROB1 and PROB2 birds. Accumulative FI was not different among the experimental groups.

\section{Internal organ weight of chicks}

The data on the internal organs relative weight of the Indonesian indigenous crossbred chickens are presented in Table-3. In general, there was no significant difference in internal organs relative weight among the groups of the indigenous crossbred chickens.

\section{Hematological parameters of chicks}

The data on complete blood counts of crossbred native chickens are presented in Table- 4 . The significant difference in full blood counts was not found among treatment groups, but the number of thrombocytes tended $(p=0.09)$ to be higher in CONT than in other dietary treatment groups. The data on antibody titer against NDV and AIV vaccines are shown in Table-5. Antibody titer against NDV was higher $(p<0.05)$ in PROB1 and PROB2 when compared with that in CONT group, but the difference was not significant when compared with that in AGP group. Antibody titer against AIV was not detected in the serum of crossbred chickens during the analysis. The data on serum biochemical parameters of the Indonesian indigenous crossbred chickens are presented in Table-6. Total triglyceride concentration was lower $(p<0.05)$ in the serum of PROB2 than that in other birds. The chicks in AGP group had lower $(\mathrm{p}<0.05)$ total protein and globulin concentrations 
Table-2: Effect of multi-strain probiotic preparation in combination with vitamins and minerals on performances of the Indonesian indigenous crossbred chickens at 10 weeks of age.

\begin{tabular}{lccccrr}
\hline Items & \multicolumn{3}{c}{ Dietary treatments } & \multirow{2}{*}{ SE } & P-value \\
\cline { 2 - 5 } & CONT & AGP & PROB1 & PROB2 & & \\
\hline Live BW (g) & 881 & 865 & 838 & 830 & 15.1 & 0.09 \\
Accumulative FI $(\mathrm{g})$ & 2639 & 2646 & 2734 & 2737 & 36.6 & 0.11 \\
FCR $(\mathrm{g} / \mathrm{g})$ & $3.13^{\mathrm{c}}$ & $3.20^{\mathrm{bc}}$ & $3.42^{\mathrm{ab}}$ & $3.47^{\mathrm{a}}$ & 0.07 & 0.01 \\
\hline
\end{tabular}

CONT $=$ Chicks receiving basal diet without any additive, AGP $=$ Chicks receiving basal diet with $0.04 \%$ of zinc bacitracin, PROB1 $=$ Chicks receiving basal diet with $0.01 \%$ of commercial probiotic Bacillus subtilis preparation, PROB2: Chicks receiving basal diet with $0.5 \%$ of multi-strain probiotic preparation in combination with vitamins and minerals, BW $=$ Body weight, FI = Feed intake, FCR $=$ Feed conversion ratio, SE $=$ Standard error

Table-3: Effect of multi-strain probiotic preparation in combination with vitamins and minerals on internal organs relative weight of the Indonesian indigenous crossbred chickens.

\begin{tabular}{|c|c|c|c|c|c|c|}
\hline \multirow[t]{2}{*}{ Items (\% live BW) } & \multicolumn{4}{|c|}{ Dietary treatments } & \multirow[t]{2}{*}{ SE } & \multirow[t]{2}{*}{ p value } \\
\hline & CONT & AGP & PROB1 & PROB 2 & & \\
\hline Heart & 0.73 & 0.73 & 0.86 & 0.66 & 0.09 & 0.48 \\
\hline Liver & 2.23 & 2.24 & 2.45 & 2.22 & 0.10 & 0.37 \\
\hline Proventriculus & 0.50 & 0.53 & 0.59 & 0.53 & 0.03 & 0.22 \\
\hline Gizzard & 1.63 & 1.60 & 1.91 & 1.76 & 0.12 & 0.26 \\
\hline Spleen & 0.26 & 0.20 & 0.26 & 0.24 & 0.04 & 0.63 \\
\hline Thymus & 0.54 & 0.45 & 0.44 & 0.53 & 0.07 & 0.69 \\
\hline Bursa of Fabricius & 0.20 & 0.13 & 0.18 & 0.13 & 0.04 & 0.33 \\
\hline Duodenum & 0.58 & 0.72 & 0.66 & 0.63 & 0.05 & 0.32 \\
\hline Jejunum & 1.06 & 1.19 & 1.19 & 1.08 & 0.09 & 0.68 \\
\hline Ileum & 0.83 & 0.84 & 0.78 & 0.76 & 0.07 & 0.83 \\
\hline Caeca & 0.48 & 0.43 & 0.45 & 0.44 & 0.04 & 0.75 \\
\hline Pancreas & 0.27 & 0.33 & 0.30 & 0.29 & 0.02 & 0.17 \\
\hline
\end{tabular}

CONT=Chicks receiving basal diet without any additive, AGP=Chicks receiving basal diet with $0.04 \%$ of zinc bacitracin, PROB1 $=$ Chicks receiving basal diet with $0.01 \%$ of commercial probiotic Bacillus subtilis preparation, PROB2=Chicks receiving basal diet with $0.5 \%$ of multi-strain probiotic preparation in combination with vitamins and minerals, $B W=B o d y$ weight, $\mathrm{SE}=$ Standard error

Table-4: Effect of multi-strain probiotic preparation in combination with vitamins and minerals on complete blood counts of the Indonesian indigenous crossbred chickens.

\begin{tabular}{lcccccc}
\hline Items & \multicolumn{3}{c}{ Dietary treatments } & SE & p-value \\
\cline { 2 - 5 } & CONT & AGP & PROB1 & PROB2 & & \\
\hline Hemoglobin $(\mathrm{g} / \mathrm{dL})$ & 10.0 & 9.12 & 10.2 & 9.67 & 0.50 & 0.39 \\
Erythrocytes $\left(10^{6} / \mu \mathrm{L}\right)$ & 2.05 & 1.94 & 2.07 & 2.01 & 0.10 & 0.76 \\
Hematocrit $(\%)$ & 28.7 & 26.4 & 29.4 & 27.4 & 1.41 & 0.43 \\
Leukocytes $\left(10^{3} / \mu \mathrm{L}\right)$ & 28.0 & 29.3 & 27.8 & 23.1 & 2.97 & 0.41 \\
Heterophils $\left(10^{3} / \mu \mathrm{L}\right)$ & 1.84 & 1.95 & 1.62 & 1.18 & 0.37 & 0.42 \\
Eosinophils $\left(10^{3} / \mu \mathrm{L}\right)$ & 1.74 & 1.65 & 1.76 & 1.35 & 0.15 & 0.18 \\
Lymphocytes $\left(10^{3} / \mu \mathrm{L}\right)$ & 24.4 & 25.7 & 24.4 & 20.5 & 2.63 & 0.48 \\
Thrombocytes $\left(10^{3} / \mu \mathrm{L}\right)$ & 18.8 & 14.3 & 15.8 & 14.7 & 1.33 & 0.09 \\
\hline
\end{tabular}

CONT $=$ Chicks receiving basal diet without any additive, AGP $=$ Chicks receiving basal diet with $0.04 \%$ of zinc bacitracin, PROB1 $=$ Chicks receiving basal diet with $0.01 \%$ of commercial probiotic Bacillus subtilis preparation, PROB2=Chicks receiving basal diet with $0.5 \%$ of multi-strain probiotic preparation in combination with vitamins and minerals, $\mathrm{SE}=$ Standard error

in the serum as compared to CONT and PROB1 chicks, but the difference was not substantial when compared with those in PROB2 chicks. Moreover, serum albumin concentration was lower $(\mathrm{p}<0.05)$ in PROB2 than that in CONT and PROB1 birds, but it did not significantly differ from that in AGP birds. Albumin to globulin $(A / G)$ ratio tended $(p=0.06)$ to be higher in AGP as compared to other birds.

\section{Bacterial population in the ileum of chicks}

The populations of selected bacteria in the ileum of the Indonesian indigenous crossbred chickens are shown in Table-7. Lactose-negative Enterobacteriaceae tended $(p=0.07)$ to be lower in PROB1 and PROB2 groups as compared to CONT group. There was also a tendency $(\mathrm{p}=0.06)$ that birds in PROB1 and PROB2 had higher numbers of LAB as compared to CONT and AGP birds. The numbers of enterobacteria and coliform bacteria were not different among the treatment groups.

\section{Carcass traits of chicks}

The data on carcass traits of crossbred chickens are presented in Table-8. In general, the significant 
Table-5: Effect of multi-strain probiotic preparation in combination with vitamins and minerals on antibody titer against NDV and AIV of Indonesian indigenous crossbred chickens.

\begin{tabular}{lcccccc}
\hline Items $\left(\right.$ Log $\left._{\mathbf{2}} \mathbf{G M T}\right)$ & \multicolumn{3}{c}{ Dietary treatments } & SE & p-value \\
\cline { 2 - 5 } & CONT & AGP & PROB1 & PROB2 & & \\
\hline Antibody titer against NDV & $2.00^{\mathrm{b}}$ & $2.83^{\mathrm{ab}}$ & $3.33^{\mathrm{a}}$ & $3.00^{\mathrm{a}}$ & 0.29 & 0.03 \\
Antibody titer against AIV & $\mathrm{ND}$ & $\mathrm{ND}$ & $\mathrm{ND}$ & $\mathrm{ND}$ & - & NA \\
\hline
\end{tabular}

CONT $=$ Chicks receiving basal diet without any additive, $A G P=$ Chicks receiving basal diet with $0.04 \%$ of zinc bacitracin, PROB1 $=$ Chicks receiving basal diet with $0.01 \%$ of commercial probiotic Bacillus subtilis preparation, $\mathrm{PROB} 2=\mathrm{Chicks}$ receiving basal diet with $0.5 \%$ of multi-strain probiotic preparation in combination with vitamins and minerals, $\mathrm{NDV}=$ Newcastle disease virus, AIV=Avian influenza virus, GMT=Geometric mean titer, $\mathrm{SE}=\mathrm{Standard}$ error, ND=Not detected (not reached detection level), NA=Not statistically analyzed

Table-6: Effect of multi-strain probiotic preparation in combination with vitamins and minerals on serum biochemical parameters of the Indonesian indigenous crossbred chickens.

\begin{tabular}{lcccccc}
\hline \multirow{2}{*}{ Items } & \multicolumn{3}{c}{ Dietary treatments } & SE & p-value \\
\cline { 2 - 5 } & CONT & AGP & PROB1 & PROB2 & & \\
\hline Total cholesterol $(\mathrm{mg} / \mathrm{dL})$ & 104 & 109 & 111 & 91.9 & 9.70 & 0.50 \\
HDL $(\mathrm{mg} / \mathrm{dL})$ & 58.2 & 56.0 & 52.8 & 63.2 & 5.19 & 0.56 \\
LDL $(\mathrm{mg} / \mathrm{dL})$ & 30.3 & 35.6 & 39.8 & 23.9 & 9.25 & 0.62 \\
Total triglyceride $(\mathrm{mg} / \mathrm{dL})$ & $104^{\mathrm{a}}$ & $91.1^{\mathrm{a}}$ & $92.5^{\mathrm{a}}$ & $57.3^{\mathrm{b}}$ & 9.55 & 0.01 \\
Total protein $(\mathrm{g} / \mathrm{dL})$ & $5.02^{\mathrm{a}}$ & $3.77^{\mathrm{b}}$ & $5.03^{\mathrm{a}}$ & $4.47^{\mathrm{ab}}$ & 0.30 & 0.02 \\
Albumin $(\mathrm{g} / \mathrm{dL})$ & $1.67^{\mathrm{a}}$ & $1.50^{\mathrm{ab}}$ & $1.68^{\mathrm{a}}$ & $1.43^{\mathrm{b}}$ & 0.06 & 0.02 \\
Globulin $(\mathrm{g} / \mathrm{dL})$ & $3.35^{\mathrm{a}}$ & $2.27^{\mathrm{b}}$ & $3.35^{\mathrm{a}}$ & $3.03^{\mathrm{ab}}$ & 0.29 & 0.04 \\
A/G ratio & 0.51 & 0.71 & 0.54 & 0.49 & 0.06 & 0.06 \\
\hline
\end{tabular}

CONT $=$ Chicks receiving basal diet without any additive, AGP=Chicks receiving basal diet with $0.04 \%$ of zinc bacitracin, PROB1 $=$ Chicks receiving basal diet with $0.01 \%$ of commercial probiotic Bacillus subtilis preparation, PROB2=Chicks receiving basal diet with $0.5 \%$ of multi-strain probiotic preparation in combination with vitamins and minerals, $\mathrm{HDL}=$ High-density lipoprotein, $\mathrm{LDL}=\mathrm{Low}$-density lipoprotein, $\mathrm{A} / \mathrm{G}$ ratio=Albumin to globulin ratio

Table-7: Effect of multi-strain probiotic preparation in combination with vitamins and minerals on selected bacterial populations in the ileum of the Indonesian indigenous crossbred chickens.

\begin{tabular}{lcccccc}
\hline Items (log cfu/g) & \multicolumn{3}{c}{ Dietary treatments } & \multirow{2}{*}{ SE } & \multirow{2}{*}{ p-value } \\
\cline { 2 - 5 } & CONT & AGP & PROB1 & PROB2 & & \\
\hline Enterobacteria & 5.50 & 5.31 & 5.16 & 5.15 & 0.26 & 0.75 \\
Coliform bacteria & 5.08 & 4.98 & 5.12 & 5.07 & 0.26 & 0.98 \\
Lactose-negative enterobacteriaceae & 5.11 & 4.10 & 3.41 & 3.56 & 0.46 & 0.07 \\
LAB & 7.30 & 7.12 & 7.75 & 7.67 & 0.18 & 0.06 \\
\hline
\end{tabular}

CONT $=$ Chicks receiving basal diet without any additive, AGP=Chicks receiving basal diet with $0.04 \%$ of zinc bacitracin, PROB1 $=$ Chicks receiving basal diet with $0.01 \%$ of commercial probiotic Bacillus subtilis preparation, PROB2=Chicks receiving basal diet with $0.5 \%$ of multi-strain probiotic preparation in combination with vitamins and minerals, $\mathrm{LAB}=$ Lactic acid bacteria, SE=Standard error

Table-8: Effect of multi-strain probiotic preparation in combination with vitamins and minerals on carcass traits of the Indonesian indigenous crossbred chickens.

\begin{tabular}{|c|c|c|c|c|c|c|}
\hline \multirow[t]{2}{*}{ Items } & \multicolumn{4}{|c|}{ Dietary treatments } & \multirow[t]{2}{*}{ SE } & \multirow[t]{2}{*}{ p-value } \\
\hline & CONT & AGP & PROB1 & PROB2 & & \\
\hline \multicolumn{7}{|c|}{ (\% live weight) } \\
\hline Eviscerated carcass & 63.5 & $\begin{array}{l}65.9 \\
(\% \text { ev }\end{array}$ & $\begin{array}{c}62.0 \\
\text { carcass) }\end{array}$ & 64.7 & 1.18 & 0.14 \\
\hline Breast & 23.5 & 22.6 & 23.4 & 23.7 & 0.52 & 0.51 \\
\hline Thigh & 15.9 & 15.3 & 15.2 & 15.8 & 0.25 & 0.16 \\
\hline Drumstick & 15.7 & 15.4 & 15.0 & 15.3 & 0.33 & 0.54 \\
\hline Wing & 14.1 & 14.7 & 14.4 & 14.2 & 0.27 & 0.41 \\
\hline Abdominal fat & 0.47 & 0.53 & 0.36 & 0.54 & 0.21 & 0.91 \\
\hline
\end{tabular}

CONT=Chicks receiving basal diet without any additive, AGP=Chicks receiving basal diet with $0.04 \%$ of zinc bacitracin, PROB1 $=$ Chicks receiving basal diet with $0.01 \%$ of commercial probiotic Bacillus subtilis preparation, PROB2=Chicks receiving basal diet with $0.5 \%$ of multi-strain probiotic preparation in combination with vitamins and minerals, $\mathrm{SE}=$ Standard error 
difference was not observed with regard to the relative weight of eviscerated carcass, breast, thigh, drumstick, wing, and abdominal fat among the chicks.

\section{Discussion}

In the present study, the chicks reached the BW of $854 \pm 38.5 \mathrm{~g}$ at week 10 . This finding was concomitant with Pramono [1] and Widodo et al. [4] reporting that the average BW of the Indonesian indigenous crossbred chickens was $850 \mathrm{~g}$ at week 8-10. Data in the present study did not show any effect of AGP and probiotic treatments on the final $\mathrm{BW}$ of the Indonesian indigenous crossbred chickens. Indeed, FCR was higher in chicks fed a diet containing either commercial $B$. subtilis or multi-strain probiotic preparation in combination with vitamins and minerals, when compared with that in CONT birds. The exact reason for the latter condition remains unclear, but the unbalanced proportion of male and female chicks among treatment groups may be responsible. At the beginning of this study sexing was not conducted and, unfortunately, at the end of the study more male chicks were seen in CONT group than in other treatment groups. Note that male chicks generally have higher and lower final BW and FCR, respectively, when compared with female ones [19]. In Indonesia, the indigenous crossbred chickens are generally produced by the traditional breeders. Unlike modern broiler strains, sexing is not commonly done in the Indonesian indigenous crossbred chickens [13]. The traditional breeders may not be able to employ trained professionals to do vent sexing (accurate sexing method) in chicks. If necessary, the traditional breeders may only perform feather sexing, but the results are less accurate for the indigenous crossbred chicks $[13,20]$. These aforementioned conditions may explain why sexing is not practicable for 1-day-old Indonesian indigenous crossbred chicks. Referring to the above circumstances and also to several authors who used unsexed chicks during the chicken studies [21-23], we therefore, decided to use unsexed indigenous crossbred chicks during the present trial. In this study, FCR was not different between PROB1 and PROB2 chicks, suggesting that multi-strain probiotic preparation in combination with vitamins and minerals may exert the same effects as commercial B. subtilis. However, multi-strain probiotic preparation in combination with vitamins and minerals may not be able to substitute the role of AGP in crossbred chickens, as the FCR was higher in PROB2 than in AGP birds.

There was a tendency that AGP and probiotic treatments resulted in lower values of thrombocytes when compared with control. Ferdous et al. [24,25] pointed out that thrombocytes can be an indicator of inflammation (as a result from infections), and that the increased thrombocytes levels may be attributable to infections in the body of animals. In this respect, the lower levels of thrombocytes in the AGP and probiotic treated chicks may suggest the lower infection levels in the respective birds. This inference was supported by another fact in the present study that AGP and probiotic treatments resulted in higher levels of antibody titer against NDV, and thus more protective primarily to ND. Allan and Gough [26] suggested that HI titers of below $3 \log _{2}$ are regarded as negative for specific immunity against ND, and such condition was found in CONT birds in the present study. The mechanisms through which probiotics increase the antibody titer of chicks were largely unknown, but such microorganisms may modulate the immune system resulting in improved immune responses of birds [6]. Different from antibody titer against NDV, antibody titer against AIV was not detected in the present study. In the earlier study, Rahman et al. [27] reported that the HI antibody titers declined with the time postvaccination. In this trial, AI vaccination was conducted on day 0 , and therefore the HI antibody titers against AIV may no longer be detected at week 8 .

Result in the present study showed that serum total protein and globulin concentrations were lower in AGP when compared with those in other groups. It was apparent in this study that the lower level of total protein in AGP birds was a consequence of the lower globulin in the respective birds. It has been clear from the previous study that the lowered serum globulin concentration was attributed to the damage of hepatocytes in animals $[28,29]$. With regard particularly to AGP chicks, zinc bacitracin administration seemed to induce dysbiosis (disruption of commensal bacterial community in the intestine) in crossbred chicks $[30,31]$. The latter condition may damage the intestinal barrier and induce bacterial translocation resulting in liver damage [32]. In this study, AGP birds had higher $\mathrm{A} / \mathrm{G}$ ratio when compared with other birds. In such case, the relatively lower serum globulin concentration in AGP birds than in other birds may be responsible. In addition to dysbiosis, the lower globulin concentration in AGP birds was also most likely due to coccidian infection in the respective birds. Gao et al. [33] reported that coccidian infection was associated with the lowered total protein and globulin levels in the serum of broilers. Similarly, Ola et al. [34] showed that coccidian infection resulted in decreased total proteins, albumin, and globulin with an increase of $A / G$ ratio in broiler chickens. In respect to albumin, result in the present study showed that albumin concentration was lowest in PROB2 birds. It has been suggested that higher serum albumin concentration was attributed to the higher BW gain of broiler chickens [35]. Furthermore, Dong et al. [36] reported that fat birds had higher serum albumin concentration than lean broilers. In accordance with these earlier reports, we found the lower albumin concentration in PROB2 birds was associated with the lower live BW and higher FCR in the respective birds.

In this study, total triglyceride was lower in the serum of PROB2 compared to that in other birds. This was in accordance with Yang et al. [37] reporting 
a decrease in total plasma triglyceride in broilers treated with B. subtilis KT260179. Furthermore, Hatab et al. [38] reported that probiotic B. subtilis and Enterococcus faecium decreased the concentration of triglyceride in the serum of broiler chicks. The present finding may, therefore, indicate that probiotic Bacillus was capable of reducing lipid synthesis and/or increasing lipid hydrolysis in the liver [37], resulting in lower concentration of triglyceride in the circulation of the Indonesian indigenous crossbred chickens. However, it is difficult to infer that the decreased serum total triglyceride level in PROB2 birds was simply due to probiotic effect, as the level of total triglyceride in the serum of PROB1 did not differ from that in CONT and AGP groups. It was shown by Hung et al. [39] that Bacillus coagulans ATCC 7050 had no effect on the serum triglyceride level of broiler chicks, which were concomitant with the absence effect of commercial B. subtilis on the serum triglyceride of PROB1 birds. In this respect, certain vitamins and minerals (administrated in combination with probiotics) in PROB2 group may contribute in lowering the level of serum triglyceride of chicks. Our latter inference was supported by Kanchana and Jeyanthi [40] showing the decreased total cholesterol and triglyceride in the plasma of layer chickens with feeding Vitamin E and/or Selenium.

It was shown in the present study that both probiotic treatments (PROB1 and PROB2) decreased the number of lactose-negative Enterobacteriaceae (included in this group among others Salmonella, Proteus, and Pseudomonas aeruginosa and Shigella) in the ileal digesta of crossbred chickens. Moreover, the treatment increased the number of LAB in the ileum of chicks. In accordance with our data, Jeong and Kim [41] demonstrated that feeding B. subtilis $\mathrm{C}-1302$ decreased and increased the numbers of Salmonella and Lactobacillus, respectively, in the ileal digesta and excreta of broiler chickens. Hence, feeding Bacillus probiotics may produce favorable effects on the intestinal health and reduce the risk of infections in the Indonesian indigenous crossbred chickens. The mode of actions by which Bacillus probiotics decreased the counts of lactose-negative Enterobacteriaceae was not exactly known, but Bacillus may produce antibiotics, enzymes or both that can kill or inhibit the growth of harmful bacteria [41]. Bacillus may also lower the intestinal $\mathrm{pH}$ and thus inhibit the proliferation of detrimental bacteria [42]. Unlike the pathogenic bacteria, the intestinal acidification (as a result of Bacillus treatment) may favor the growth of LAB in the intestine of chicks $[41,42]$. The latter condition seemed to explain the increased number of LAB in the intestine of Bacillus-treated chicks in the present study.

It was apparent in the present study that dietary treatments did not produce any effect on carcass traits of the Indonesian indigenous crossbred chickens.
Concomitant to our finding, treatment with either AGP [12,16], commercial B. subtilis [43] or multistrain probiotic preparation in combination with vitamins and minerals $[11,12]$ had no impact on the carcass traits of broiler chicks. Different from the above-mentioned studies, Shabani et al. [44] and Fouad et al. [45] showed the potential of probiotics in increasing the carcass percentage of broiler chickens. The different type of probiotics, breed of chickens, and conditions of the trial may be responsible for these different results above.

It seemed in the present study that the role of vitamins and minerals added to probiotic preparation (PROB2) had a minimum effect on the chicks. This inference was supported by the current findings showing a comparable effect of commercial $B$. subtilis and multi-strain probiotic preparation in combination with vitamins and minerals to most of parameters observed in the present study. Supplementation of certain minerals and vitamins into probiotic preparation was actually intended to compensate the possible damage of vitamins and minerals in the feed due to improper feed handling during transportation and storage [11]. Furthermore, supplementation was subjected to alleviate the detrimental effects of unfavorable conditions such as heat stress on poultry [8]. Indeed, Tirawattanawanich et al. [46] revealed that Thai indigenous crossbred chickens had a better tolerance to heat stress than modern broiler chickens. Due to the latter study and the fact that the experiment was conducted during the rainy season (average temperature during the day was $30^{\circ} \mathrm{C} \pm 2^{\circ} \mathrm{C}$ ), the vitamins and minerals supplementation seemed to produce minimal effect as the Indonesian indigenous crossbred chickens less suffered from heat stress.

\section{Conclusion}

It could be concluded from the present study that multi-strain probiotic preparation in combination with vitamins and minerals was able to improve immune response and control the potentially pathogenic bacteria. However, the additive failed to improve the growth performance of the Indonesian indigenous crossbred chickens.

\section{Authors' Contributions}

SS designed, performed the work and wrote the manuscript, TY, EW, and HIW performed the work and revised the manuscript and II performed the data analysis.

\section{Acknowledgments}

The study was funded by the Faculty of Animal and Agricultural Sciences, Diponegoro University, Semarang through the Faculty Research Grant No:/ UN7.5.5/PP/2018.

\section{Competing Interests}

The authors declare that they have no competing interests. 


\section{References}

1. Pramono, D. (2006) Ayam hasil persilangan sebagai alternatif pengembangan usaha ternak unggas. Proseding Lokakarya Nasional Inovasi Teknologi dalam Mendukung Usaha Ternak Unggas Berdaya Saing. Puslitbang Peternakan, Bogor (article in Indonesian language).

2. Muryanto. (2005) Pengembangan ayam hibrida (ayam potong lokal). Petunjuk Teknis. Balai Pengkajian Teknologi Pertanian Jawa Tengah, Ungaran (article in Indonesian language).

3. Ma'rifah, B., Atmomarsono, U. and Suthama, N. (2013) Nitrogen retention and productive performance of crossbred native chicken due to feeding effect of kayambang (Salvinia molesta). Int. J. Sci. Eng., 5: 19-24.

4. Widodo, W., Rahayu, I.D., Sutanto, A. and Anggraini, A.D. (2017) Penambahan lempuyang dalam pakan ayam kampung super yang menggunakan campuran jamu. Seminar Nasional dan Gelar Produk, 17-18 October 2017, Malang, East Java Province, Indonesia (article in Indonesian language).

5. Krista, B. and Harianto, B. (2011) Petunjuk praktis pembesaran ayam kampung pedaging. Agromedia Pustaka, Jakarta (article in Indonesian language).

6. Sugiharto, S. (2016) Role of nutraceuticals in gut health and growth performance of poultry. J. Saudi Soc. Agric. Sci., 15: 99-111.

7. Simon, O. (2005) Micro-organisms as feed additives - probiotics. Adv. Pork Prod., 16: 161-167. Available from http://www.prairieswine.com/pdf/2451.pdf. Last accessed on 20-02-2018.

8. Sugiharto, S., Yudiarti, T., Isroli, I., Widiastuti, E. and Putra, F.D. (2017) Effect of dietary supplementation with Rhizopus oryzae or Chrysonilia crassa on growth performance, blood profile, intestinal microbial population, and carcass traits in broilers exposed to heat stress. Arch. Anim. Breed., 60: 347-356.

9. Winkler, P., de Vrese, M., Laue, CH. and Schrezenmeir, J. (2005) Effect of a dietary supplement containing probiotic bacteria plus vitamins and minerals on common cold infections and cellular immune parameters. Int. J. Clin. Pharmacol. Ther., 43: 318-326.

10. Isroli, I., Yudiarti, T., Widiastuti, E. and Sugiharto, S. (2017) Probiotic Bacillus plus vitamins and minerals enhanced haemoglobin values and relative weight of ileum and improved feed conversion ratio of broilers during brooding period. Livest. Res. Rural Dev. Available from: http://www.lrrd.org/ lrrd29/11/sgh29212.html. Last accessed on 18-02-2018.

11. Sugiharto, S., Isroli, I., Yudiarti, T. and Widiastuti, E. (2018) The effect of supplementation of multistrain probiotic preparation in combination with vitamins and minerals to the basal diet on the growth performance, carcass traits, and physiological response of broilers. Vet. World, 11: 240-247.

12. Sugiharto, S., Isroli, I., Yudiarti, T. and Widiastuti, E. (2018) The effect of zinc bacitracin and Bacillus mixture administration to the low day-old weight chick diets on the physiological response. Poult. Sci. J., 6: 51-62.

13. Kusumawati, A., Febriany, R., Hananti, S., Dewi, M.S. and Istiyawati, N. (2016) Perkembangan embrio dan penentuan jenis kelamin DOC (day-old chicken) ayam Jawa super. $J$. Sain Vet., 34: 29-41 (article in Indonesian language).

14. Bolton, W. (1967) Poultry Nutrition. MAFF Bulletin No.174. HMSO, London.

15. SNI (Indonesian National Standard). (2006) Standard for Broiler Feed (SNI 01-3930-2006). National Standardization Agency of Indonesia, Jakarta, Indonesia.

16. Sugiharto, S., Yudiarti, T., Isroli, I., Widiastuti, E. and Putra, F.D. (2017) Effects of feeding cassava pulp fermented with Acremonium charticola on growth performance, nutrient digestibility and meat quality of broiler chicks. S. Afr. J. Anim. Sci., 47: 130-138.

17. Villegas, P. (1987) Avian virus diseases laboratory manual.
College of Veterinary Medicine. University of Georgia, Athens, Georgia, USA.

18. Sugiharto, S., Yudiarti, T., Isroli, I., Widiastuti, E., Putra, F.D. (2017) Intestinal microbial ecology and hematological parameters of broiler fed cassava waste pulp fermented with Acremonium charticola. Vet. World, 10: 324-330.

19. Awad, E.A., Zulkifli, I., Soleimani, A.F. and Aljuobori, A. (2017) Effects of feeding male and female broiler chickens on low-protein diets fortified with different dietary glycine levels under the hot and humid tropical climate. Italian $J$. Anim. Sci., 16: 453-461.

20. Nandi, S., McBride, D., Blanco, R. and Clinton, M. (2003) Avian sex diagnosis and sex determination. World's Poult. Sci. J., 59: 8-14.

21. Flock, D.K. and Seeman, G. (1993) Limits to genetic improvements of broiler stocks? Arch. Gefl., 57: 107-112.

22. Ellendorff, F. and Klein, S. (2003) Current knowledge on sex determination and sex diagnosis: Potential solutions. World's Poult. Sci., 59: 7.

23. Ullah, Z., Yousaf, M., Shami, M.M., Sharif, M. and Mahrose, K.H. (2018) Effect of graded levels of dietary corn steep liquor on growth performance, nutrient digestibility, haematology and histopathology of broilers. J. Anim. Physiol. Anim. Nutr., 102: e395-e402.

24. Ferdous, F., Maurice, D. and Scott, T. (2008) Broiler chick thrombocyte response to lipopolysaccharide. Poult. Sci., 87: 61-63.

25. Ferdous, F., Saski, C., Bridges, W., Burns, M., Dunn, H., Elliott, K. and Scott, T.R. (2016) Transcriptome profile of the chicken thrombocyte: New implications as an advanced immune effector cell. PLOS ONE, 11: e0163890.

26. Allan, W.H. and Gough, R.E. (1974) A standard haemagglutination inhibition test for Newcastle disease. (1). A comparison of macro and micro methods. Vet. Record., 95: 120-123.

27. Rahman, M.M., Sarker, R.D. and Nooruzzaman, M. (2017) Evaluation of serum antibody titer level against Newcastle disease virus in vaccinated broiler chickens. Ann. Vet. Anim. Sci., 4: 94-98.

28. Meissonnier, G.M., Oswald, I.P. and Galtier, P. (2005). Aflatoxicosis in swine - A bibliographic review of clinical cases and experimental data. Rev. Med. Vet., 156: 591-605.

29. Faixová, Z., Faix, S., Bořutová, R. and Leng, L. (2007). Effect of different doses of deoxynivalenol on metabolism in broiler chickens. Bull. Vet. Inst. Pulawy. 51: 421-424.

30. England, J.A., Watkins, S.E. and Saleh, E. (1996) Effects of Lactobacillus reuteri on live performance and intestinal development of male turkeys. J. Appl. Poult. Res., 5: 311-324.

31. Yegani, M. and Korver, D.R. (2008) Factors affecting intestinal health in poultry. Poult. Sci., 87: 2052-2063.

32. Mazagova, M., Wang, L., Anfora, A.T., Wissmueller, M., Lesley, S.A., Miyamoto, Y., Eckmann, L., Dhungana, S., Pathmasiri, W., Sumner, S., Westwater, C., Brenner, D.A. and Schnabl, B. (2015) Commensal microbiota is hepatoprotective and prevents liver fibrosis in mice. FASEB $J$., 29: $1043-1055$

33. Gao, J., Zhang, H.J., Wu, S.G., Yu, S.H., Yoon, I., Moore, D., Gao, Y.P., Yan, H.J. and Qi, G.H. (2009) Effect of Saccharomyces cerevisiae fermentation product on immune functions of broilers challenged with Eimeria tenella. Poult. Sci., 88: 2141-2151.

34. Ola, F.A.T., Rasha, A.E.M. and Lashin, I.A. (2017) Biochemical and immunological effect of some probiotic compounds against coccidiosis in broiler chickens. Anim. Health Res. J., 5: 93-100.

35. Sahin, K., Kucuk, O., Sahin, N. and Gursu, M.F. (2002) Optimal dietary concentration of vitamin $\mathrm{E}$ for alleviating the effect of heat stress on performance, thyroid status, $\mathrm{ACTH}$ and some serum metabolite and mineral concentrations in broilers. Vet. Med. Czech, 47: 110-116.

36. Dong, J.Q., Zhang, H., Jiang, X.F., Wang, S.Z., Du, Z.Q., 
Wang, Z.P., Leng, L., Cao, Z.P., Li, Y.M., Luan, P. and Li, H. (2015) Comparison of serum biochemical parameters between two broiler chicken lines divergently selected for abdominal fat content. J. Anim. Sci., 93: 3278-3286.

37. Yang, J., Qian, K., Zhang, W., Xu, Y. and Wu, Y. (2016) Effects of chromium-enriched Bacillus subtilis KT260179 supplementation on chicken growth performance, plasma lipid parameters, tissue chromium levels, cecal bacterial composition and breast meat quality. Lipids Health Dis., 15: 188 .

38. Hatab, M.H., Elsayed, M.A. and Ibrahim, N.S. (2016) Effect of some biological supplementation on productive performance, physiological and immunological response of layer chicks. J. Radiat. Res. Appl. Sci., 9: 185-192.

39. Hung, A.T., Lin, S.Y., Yang, T.Y., Chou, C.K., Liu, H.C., Lu, J.J., Wang, B., Chen, S.Y. and Lien, T.F. (2012) Effects of Bacillus coagulans ATCC 7050 on growth performance, intestinal morphology, and microflora composition in broiler chickens. Anim. Prod. Sci., 52: 874-879.

40. Kanchana, G. and G.P. Jeyanthi. (2010) The effect of supplementation of diet with vitamin $\mathrm{E}$ and Selenium and their combinations on the performance and lipid profiles of layer chickens. Int. J. Pharm. Bio Sci., 6: 1-11.
41. Jeong, J.S. and Kim, I.H. (2014) Effect of Bacillus subtilis C-3102 spores as a probiotic feed supplement on growth performance, noxious gas emission, and intestinal microflora in broilers. Poult. Sci. 93: 3097-3103.

42. Knap, I., Kehlet, A.B., Bennedsen, M., Mathis, G.F., Hofacre, C.L., Lumpkins, B.S., Jensen, M.M., Raun, M. and Lay, A. (2011) Bacillus subtilis (DSM17299) significantly reduces Salmonella in broilers. Poult. Sci., 90: 1690-1694.

43. Zaghari, M., Zahroojian, N., Riahi, M. and Parhizkar, S. (2015) Effect of Bacillus subtilis spore (GalliPro®) nutrients equivalency value on broiler chicken performance. Italian J. Anim. Sci., 14: 3555.

44. Shabani, R., Nosrati, M., Javandel, F. and Kioumarsi, H. (2012) The effect of probiotics on carcass and internal organs of broilers. Ann. Biol. Res., 3: 5475-5477.

45. Fouad, A.M. and El-Senousey, H.K. (2014) Nutritional factors affecting abdominal fat deposition in poultry: A review. Asian Aust. J. Anim. Sci., 27: 1057-1068.

46. Tirawattanawanich, C., Chantakru, S., Nimitsantiwong, W. and Tongyai, S. (2011) The effects of tropical environmental conditions on the stress and immune responses of commercial broilers, Thai indigenous chickens, and crossbred chickens. J. Appl. Poult. Res., 20: 409-420. 